\title{
Mihajlo I. Pupin Biography
}

\section{Petar Vuca}

In October this year it will be 160 years since Pupin's birth and 120 years since he obtained his PhD. When travelling by road from Zrenjanin to Belgrade there is a board indicating IDVOR. "This place sounds somehow familiar to me?", asked my travel companion. "It's the birthplace of our Mihajlo Pupin, a world famous scientist and a great philanthropist", I answered.

Mihajlo I. Pupin was born on October 9, 1854 in the village of Idvor, municipality of Kovačica in Banat. There are several version concerning his birthdate. The above mentioned date was accepted by Pupin huimself as a correct one. Hi is of Serbian nationality, but at that time Banat was a part of the Austro-Hungarian Monarchy.

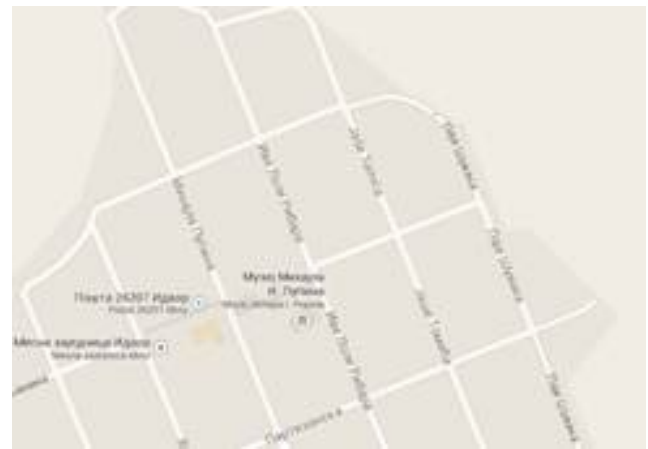

His father Kosta and mother Olimpijada had 10 children, but only Mihajlo and his three older sisters stayed alive.

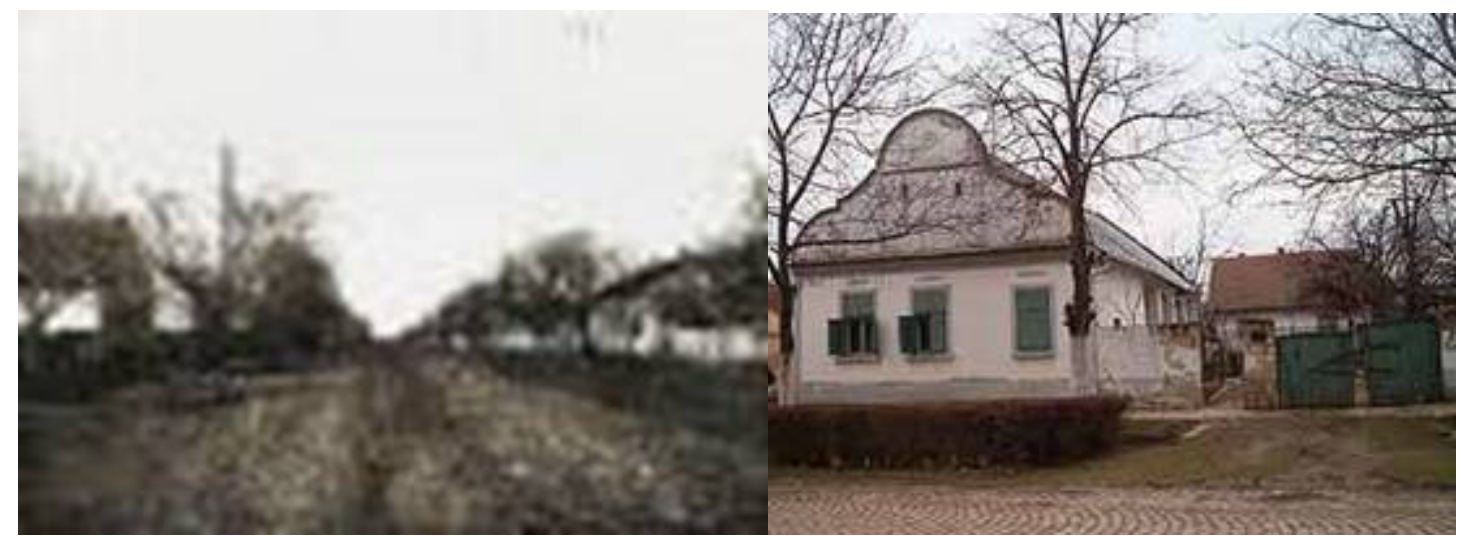

Muddy road leading to Pupin's birth house and renovated Pupin's house in Idvor

Mihajlo's parents were illiteral and, according to Mihailo himself, intelligent and well-respected people who brought up their children in a patriarchal manner. Mihajlo's father was a Knez. Mihailo carried out agricultural work together with his father and tended oxen together with other sheperds even when he was a student of secondary school in Pancevo. He went in elementary school in his birthplace, Idvor, and then continued his schooling at a German high school in Pancevo. Šimon (according to some sources Simon) Kos, a physics teacher at Pancevo Real Gymnasium, had a partcularly prominent place among many persons who had influence to Pupin's determination and world view Kos was a good educator and a skilled interpreter of natural phenomena and physical laws, who awoke the interest of young Pupin in physics, particularly in electrical phenomena. Pupin was extremly talented student and Simon Kos recommended him to continue his education abroad. This was supported and suggested to Pupin's parents by the teacher and the first prieste Vasa Zivkovic. Mihajlo's mother agreed and sent Mihajlo to Prague in 1872. Pupin's mother Olimijada (1814-1886) was a person who he admired and who directed him through his life. She was born in Opovo, her parents were Tanasije i Marija Milovanovic (known as Aleksici), and she married Konstantin in 1823. 
In Prague, Pupin finished six grade of German Real Gymnasium. However, he did not continued this schooling, but on March 12, 1874, when he was twenty and with a little money in his pocket, started a long and uncertain journey to America by "Westphalia" ship, via Hamburg. He arrived in New York after a forty-day journey. He experienced a very hard time in the first five years of living in America. He worked as a manual worker and in a biscuit factory in New York. He often visited Cooper Library where he prepared for entrance examination at a college. In autumn 1879 he passed entrance examination at Columbia College with high grades and therefore was exempted from paying tuition fees. He earned his living by giving private lessons in mathematics and physics.

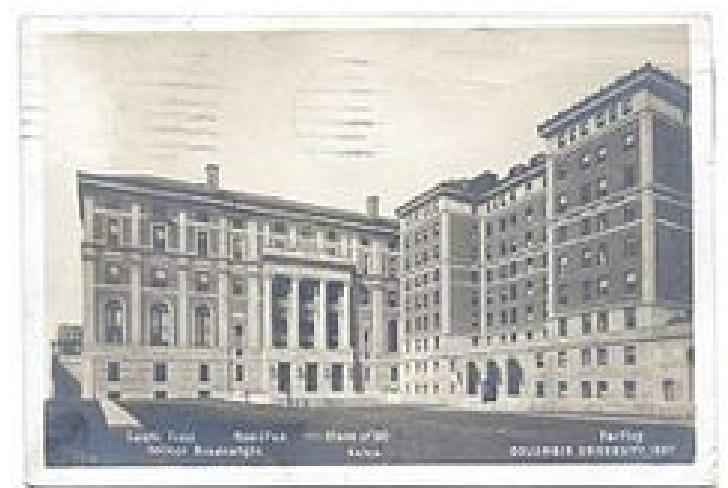

Hamilton and Hartley Halls of Columbia University's campus, year 1907

In 1883 Pupin graduated and became U.S. citizenship. He received schoolarship to study mathematics and physics at Cambridge in England (1883-1885). Afterwards, craving for knowledge, he went to study physics in Vienna (1885-1889) where he worked with a famous theoretical and experimental physic Helmholtz. He obtained his Ph.D. under Helmoltz in the field of physical chemistry with the thesis entitled "Osmotic pressure and its relationship to free energy".

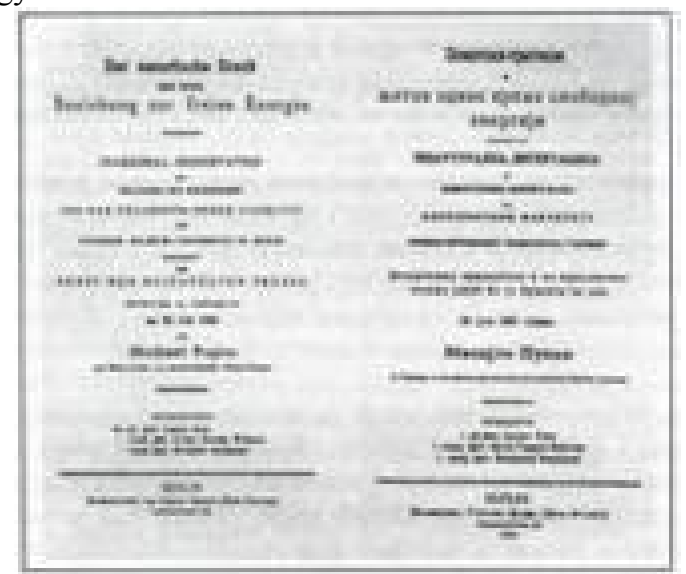

Head page of Pupin's doctor dissertation

In 1888, in London, he married Sarah Catharine Jackson from New York, with whom he had a daughter named Varvara (Barbara). Sara was the sister of his friend and a future colleague Villiam Jackson. 


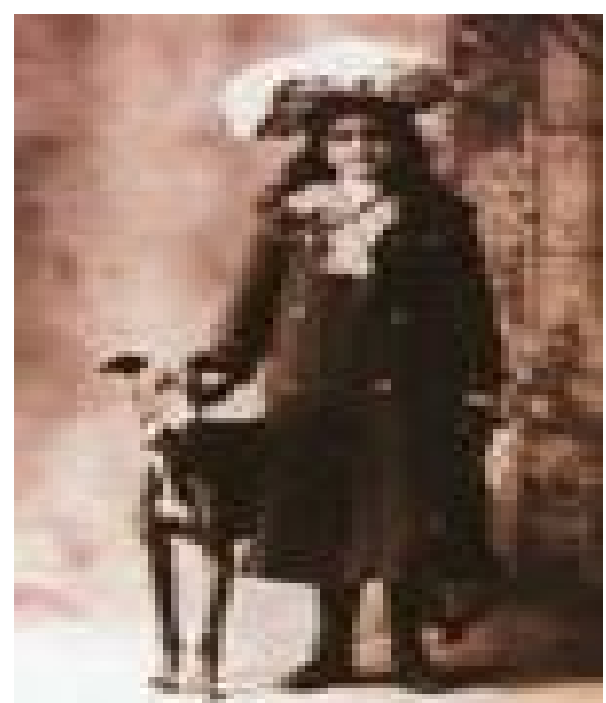

Pupin's daughter Varvara - work by Paja Jovanovic

In 1889 Pupin returned to America and started his reach academic career as a lecturer of mathematical physics in the Department of Electrical Engineering in the School of Mines of Columbia University. Mihajlo was a professor at Columbia University from 1889 to 1929. He also began scientific research. His first scientific works regarding current flow through diluted gases are from that period. When the conflict between the supporters of direct and alternating current occurred, Putin supported his countryman Nikola Tesla. In the period 1892-1895 Pupin studied electrical resonance phenomenon. He managed to perform for a complex alternating current the same analysis as his teacher Helmholtz performed for sound. In 1896 Mihailo conducted experiments with fluoresecent screen which use shortened exposure time from one hour to several minutes. This was the discovery of secondary X-rays used for medical purposes even today.

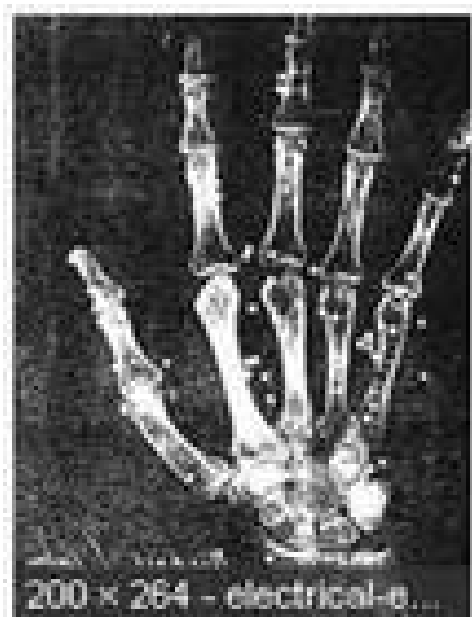

Pupin's radiography of Budler Prescott's hand, the firt radiography in USA

On April 15, 1896 Pupin got ill from pneumonia, the same disease from which his wife died. Her death was very difficult for him so that he went with his daughter to Norfolk where he bought an estate. During his pedagogic work he had many students that later became famous scientists, like Miliken and Langmore. Pupin was selected the president or vice-president of the highest scientific and technical institutions, such as the New York Academy of Sciences, the American Institute of Electrical Engineers, etc. Pupin published many books, particularly noteworthy are The New Reformation (1927) and Romance of the Machine (1930). In 1923 he wrote his autobiography From Immigrant to Inovator for which he won Pulitzer Prize in 1924. This book was first published in Serbian in 1929 under the title From Pastures to Scientist. Mihajlo was the 8th member at the founding meeting of the National Advisory Committee for Aeronautics (NACA) held in the office of the United States Department of War on April 23, 1915. In 1958 NACA was absorbed in the new space agency NASA. Together with the colleauges Pupin laid the foundations of contemporary space exploration. A year later, in 1924, Pupin developed many inventions, and 24 of them were registered/patented. He won many prizes and rewards for his comprehensive work. Pupin is an inventor of world importance in three fields: 
telecommunication, radio technics and radiology. Columbia University's Physical Laboratories building, built in 1927, is named Pupin Physics Laboratories, also known as Pupin Hall, in his honor.

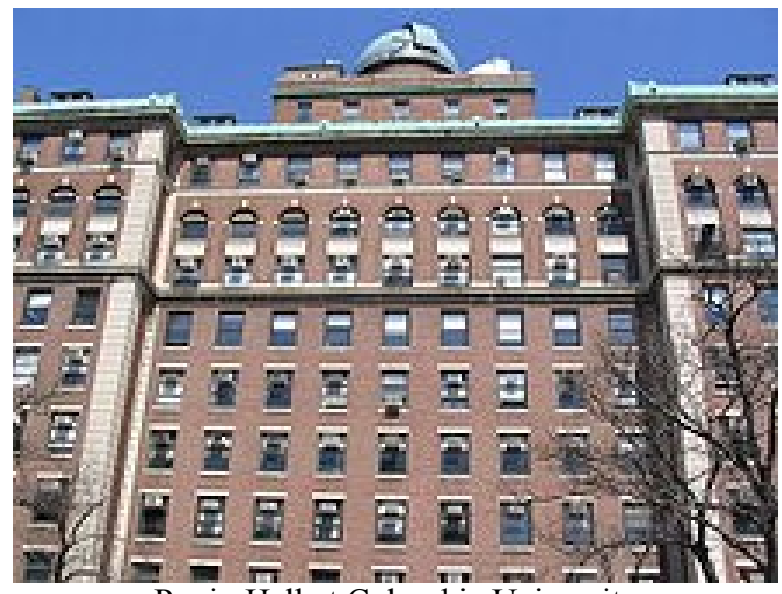

Pupin Hall at Columbia University

Pupin's inventions are mainly in the filed of telephony, telegraphy and radio technics. He gained global reputation by inveting the process of pupinization enabling long-distance telegraphic or telephonic transmission, which previously was not possible. The process was named by Pupin. Electric resonance, as a subject of study, attracted his attention in the period 1892 and resulted in invention of electrical circuit universally used today in all radio connections. He sold the patent of electrical circuit to the Marconi Company. During the World War I Pupin and his associates were doing research work with the aim of developing a system of submarine detection and a system of telephonic communication in air traffic. In this laboratory, while Pupin was still alive, Harold Urey discovered heavy hydrogen, for which he was awarded the Nobel Prize in 1934.

Mihajlo Pupin died in New York on March 12, 1935 and was buried at the Woodlawn Cemetery in the Bronx.

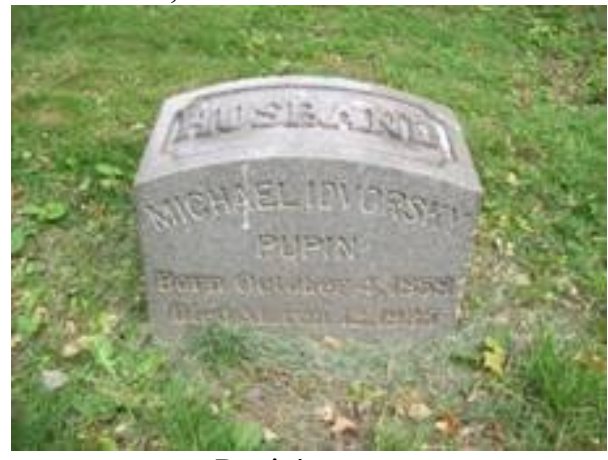

Pupin's grave

Medals and rewards: The Elliot Cresson Medal of the Franklin Institute (1902), The Hobort Prize of the French Academy (1916), The Edison Medal of the American Institute of Electrical engineers (1920), The Medal of Honor of the Radio Institute of America, The Gold Medal of the American Institute of Social Sciences, The Washington Award of the Western Society of Engineers (1928), John Fritz Medal (1932).

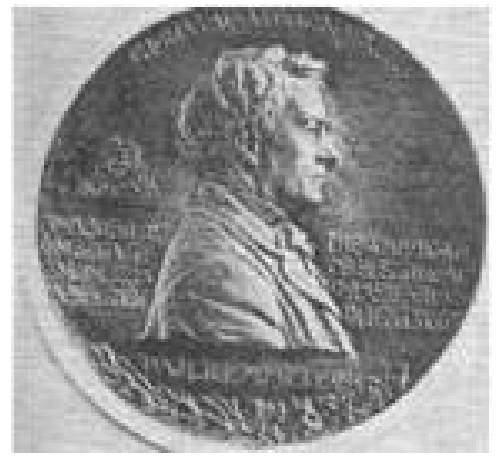

The Edison Medal of the American Institute of Electrical engineers (1919) 
Mihajlo Pupin was strongly attached to his homeland and supported it altruistically. Many schools and institutes are named after him in his honour.

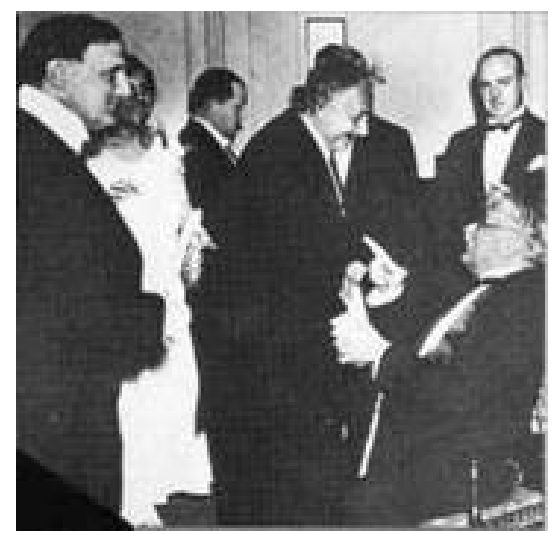

Pupin (seating) in conversation with Albert Einstein - p. 255

Pupin was the first Serbian diplomat in USA. In 1912 he was named an honorary consul in the United States and performed this dutiy until 1920. Mihajlo Pupin was a member of the National Academy of Sciences, the president of the New York Academy of Sciences, the president of the American Society of Electrical Engineering Technicians, honorary doctor of Belgrade University and many other universities, and winner of numerous rewards and prizes.

\section{Literature:}

[1]. Mihajilo I. Pupin „Sa pašnjaka do naučnika“ prevod prof. dr A. Marinčić, Zavod za udžbenike i nastavna sredstva, Beograd 1996.

[2]. Život i delo Mihajla Idvorskog Pupina, Zbornik radova naučnog skupa, Novi Sad - Idvor, 4-7. oktobra 1979, Novi Sad 1985. 